\title{
Effect of soot formed in result of coal combustion with two types of solid fuel additives on soot - soil bacteria interaction - biodegradation of soot components by soil bacteria
}

\author{
Barbara Kalicka ${ }^{1,2}$, Marek Chyc ${ }^{3,4}$, Monika Bojko1 ${ }^{1}$ Monika Olchawa-Pajor ${ }^{1,3}$ and Dariusz Latowski1,a \\ ${ }^{1}$ Department of Plant Physiology and Biochemistry, Faculty of Biochemistry, Biophysics and Biotechnology, Jagiellonian University, Gronostajowa 7 , \\ 30-387 Kraków, Poland \\ ${ }^{2}$ Department of Pharmaceutical Biochemistry, Faculty of Pharmacy, Jagiellonian University Medical College, Medyczna 9, 30-688 Kraków, Poland \\ ${ }^{3}$ Department of Environmental Protection, State Higher Vocational School in Tarnów, Mickiewicza 8, 33-100 Tarnów, Poland \\ ${ }^{4}$ Silesian Environmental Doctoral Study, Plac Gwarków 1, 40-166 Katowice, Poland
}

\begin{abstract}
During coal combustion soot formation is unwanted. There are many fuel additives used to reduce soot production. In this study toxicity and biodegradation of three types of soot by two soil bacteria strains i.e. Pseudomonas aeruginosa and Bacillus subtilis were compared. Two additives were selected to produce soot samples: (i) commonly used and containing significant quantities of $\mathrm{NaCl}$ (40-44\%) and copper (Cu-additive), (ii) newly developed without $\mathrm{NaCl}$ and with triiron tetraoxide instead of copper (Feadditive). Average number of bacterial colonies was similar when soot produced during combustion without additive and with Feadditive were used. It was about $50 \%$ higher than number of colonies when soot formed with Cu-additive was applied. The soot biodegradation was tested by HS-GC-MS analysis. The highest biodegradation level (about $80 \%$ ) was obtained for samples with $P$. aeruginosa cultures and Fe-additive soot. It can be concluded that newly developed additive does not increase toxicity of the soot to soil bacteria and will be removed more quickly from the environment.
\end{abstract}

\section{Introduction}

Coal is one of the largest sources of energy, especially for electricity generation, but it is also the largest worldwide anthropogenic source of many pollutants emitted to environment during its combustion. The main of these pollutants emitted into the atmosphere are carbon dioxide and soot. They are theorized to be the two-largest causes of global warming [1].

Soot is formed as a by-product of combustion or pyrolysis of carbon-containing materials, such as coal, wood, fuel oil, waste oil, paper, plastics, and household refuse. Although its chemical compositions and properties are highly variable and depend on the type of starting material and the combustion conditions, soot is always a chemical and physical pollutant of air, water and soil. It is known that soot is a powerful absorbent of sunlight and contributes to climate warming and melting of glaciers covered with so called dry deposition (particulates) causing the greenhouse effect [2, 3]. Soot is causing not only a greenhouse effect but also circulatory and respiratory system diseases. Because it is a mixture containing crystal amorphous carbon (black carbon), polyaromatic hydrocarbons (PAHs), persistence organic radicals [4] or heavy metals [5] it can be primarily associated with proven properties such as mutagenicity and carcinogenicity [2]. Therefore, soot reduction constitutes a significant component of air protection programmes as well as the low emission reduction programmers (LERP).

\footnotetext{
a Corresponding author: dariuszlatowski@gmail.com
}

Reduction of soot level can be achieved by using of solid fuel additives. Although additives reduce soot formation during coal combustion their influence on toxicity of soot formed in result of the combustion with these additives has not been enough documented.

The investigation of the soot effect on organisms still do not provide conclusive evidence about the pollution impact on soil microbes [6]. Similarly, the effect of various solid fuels additives on soot biodegradation by soil microbes is still unknown [7].

In this study soot produced as a result of combustion with and without solid fuel additives was tested. Two additives were selected. One was commercially available and commonly used additive containing significant quantities of $\mathrm{NaCl}$ and $\mathrm{CuSO}_{4}$ (Cu-additive). The second one was newly developed, $\mathrm{NaCl}$ free additive with triiron tetraoxide instead of copper compound (Fe-additive).

The main purpose of this work was to determine how various solid fuels additives modulate interaction soot - soil bacteria including biodegradability of soot by these microbes.

\section{Materials and methods}

\subsection{Procedure of soot formation}

Three types of soot were tested. One of them was called unmodified (UM) and no additives were used during its formation. Two other types of soot were produced with solid 
fuel additives. One of them was commercially available and commonly used additive containing significant quantities of $\mathrm{NaCl}$ i. e. $40-44 \%$ and $\mathrm{CuSO}_{4}$ (Cu-additive). The second one was newly developed, $\mathrm{NaCl}-$ and $\mathrm{CuSO}_{4}$ free additive with triiron tetraoxide (Fe-additive). All soot samples were obtained from combustion chamber of central heating system boiler (Viadrus Hercules U22, rated power $29.1 \mathrm{~kW}$ ) by the combustion of $10 \mathrm{~kg}$ of hard coal (KWK Piast) without or with additives. The Fe-additive contains triiron tetraoxide, potassium, sodium and ammonium nitrate, sodium percarbonate and anti-caking agent. This invention reduces the emission of particulate matter, $\mathrm{CO}, \mathrm{CH}_{4}$ and unburned volatile organic compounds (VOCs) exhaled with the flue gases into the atmosphere. Fe-additive maintains the surface of the fireside heat exchanger free of soot thereby increasing the thermal efficiency of the heating system. The boiler used for combustion was cleaned after burning to reduce the impact of residues prior preparation. Before burning with the fuel additive the boiler was not cleaned to achieve the appropriate amount of soot in the combustion chamber.

\subsection{Soot sterilization procedure}

To study soot - bacteria interactions samples of each soot type were grinded carefully in a mortar and sterilized.

Two methods of soot sterilization were tested. One of them was dry sterilization by UV radiation and another one was moist heat sterilization in autoclave. Soot samples (200 mg) were illuminated by UV lamp in laminar chamber for $20 \mathrm{~min}$ or sterilized in the autoclave $\left(120^{\circ} \mathrm{C}, 20 \mathrm{~min}\right)$ as a suspension in a growing medium. To control soot sterilization UVand autoclave- treated samples were placed in aseptic liquid medium LB MIX (Tab. 1) and incubated (see: 2.3. Method of bacteria culturing).

Table 1. Composition of liquid nutrient medium LB MIX used for bacteria culture $(\mathrm{pH} 7.00)$.

\begin{tabular}{|c|c|}
\hline Composition & Mass $[\mathbf{g} / \mathbf{L}]$ \\
\hline Casein peptone & 10.00 \\
\hline Yeast extract & 5.00 \\
\hline Sodium chloride & 10.00 \\
\hline
\end{tabular}

After incubation about $0.2 \mathrm{~mL}$ of medium were spread on LB MIX-agar plates, incubated $\left(24 \mathrm{~h}, 37^{\circ} \mathrm{C}\right)$ and checked whether the microorganism colonies were present. Samples were sterile if no colonies of microbes were detected.

\subsection{Method of bacteria culturing}

For the bacteria multiplication two $100 \mathrm{~mL}$ conical flasks containing $50 \mathrm{~mL}$ of sterile liquid medium LB MIX (Tab. 1) were inoculated with one of two the most common soil bacteria strains, i.e.: Pseudomonas aeruginosa or Bacillus subtilis. Then both flasks were incubated for $24 \mathrm{~h}$ at $37^{\circ} \mathrm{C}$ with shaking $(200$ RPM). Growth of liquid monocultures was monitored by optical density (OD) measurement at $600 \mathrm{~nm}$ using UV-Vis spectrophotometer. The measurements were done after 24 hours of incubation. For further experiments proper volume of each culture was taken to obtain the new cultures with the same OD value $(0.300)$ i.e. the same amount of bacteria cells.

\subsection{Influence of soot on bacterial growth}

The appropriate volumes of 24-hours bacteria cultures were used for inoculation of $50 \mathrm{~mL}$ new liquid cultures of $P$. aeruginos $a$ or $B$. subtilis. Each bacteria culture was treated by one of three types of soot (UM, Cu- or Fe- additive) and compared with control (culture without soot). The study was performed for two concentrations $(\mathrm{w} / \mathrm{v})$ of soot in the nutrient medium i.e. $0.30 \%$ and $6.00 \%(\mathrm{w} / \mathrm{v})$. Culture conditions were the same as described in paragraph 2.3. After 24 hours appropriate volume of each culture was taken, diluted with the growing medium and seeded on LB MIX - agar Petri plate. Dilution and volume of each culture were estimated so as to obtain on Petri dish number of colonies which were possible to count. All tests were repeated 10 times

\subsection{Biodegradation of soot components by soil bacteria}

Samples of each type of soot $(0.20 \mathrm{~g})$ were weighed out to $100 \mathrm{~mL}$ volume conical flask. Then each flask was filled with $50 \mathrm{~mL}$ of BSM mineral nutrient medium containing no carbon source (Tab. 2). Obtained suspensions were sterilized.

Table 2. Composition of BSM mineral nutrient medium containing no carbon source ( $\mathrm{pH} 7.00)$.

\begin{tabular}{|c|c|}
\hline Composition & Mass [g/L] \\
\hline $\begin{array}{c}\text { Potassium dihydrogen } \\
\text { phosphate }\end{array}$ & 0.38 \\
\hline $\begin{array}{c}\text { Dipotassium hydrogen } \\
\text { phosphate }\end{array}$ & 0.60 \\
\hline $\begin{array}{c}\text { Magnesium sulfate } \\
\text { heptahydrate }\end{array}$ & 0.20 \\
\hline $\begin{array}{c}\text { Ammonium chloride } \\
\text { Iron(III) chloride } \\
\text { hexahydrate }\end{array}$ & 0.08 \\
\hline
\end{tabular}

After sterilization, soot (UM, Cu-, or Fe- additive) were left as control sample (with no bacteria). Other two containing the same type of soot were inoculated with the same amount of cells one of two bacterial strains: P. aeruginosa or B. subtilis, respectively. The cultures were kept in darkness to prevent possible photolysis of sample components and incubated for 4 weeks $\left(30^{\circ} \mathrm{C}, \mathrm{RPM} 150\right)$. The test was repeated 10 times.

After 4 weeks of incubation $15 \mu \mathrm{L}$ of soot solution with bacteria from each of the flasks were collected, spread on LB MIX-agar plates and incubated $\left(24 \mathrm{~h}, 37^{\circ} \mathrm{C}\right)$ to check whether the microorganisms survived the incubation period. The rest of the solution from the flasks was filtered on a Büchner funnel under reduced pressure with a hard filter (degree: 390 , weight: $84 \mathrm{~g} / \mathrm{m}^{2}$ ). The filters with residues were placed in glass vials, allowed to dry at room temperature for 5 days and then sealed. The samples were analyzed to determinate analytes concentrations by static headspace gas chromatography with mass spectrometry detection (HS-GC- 
MS) after about 15 min of vials termostation at $150^{\circ} \mathrm{C}$ just before the gas phase injection $(50 \mu \mathrm{L})$. The analysis was performed in a gas chromatograph (Agilent Technologies 6890N Network GC system) coupled with a mass spectrometer 5975C VL MSD quadrupole type with electron beam ionization (70eV Electron Impact, EI). The injector temperature was set at $250^{\circ} \mathrm{C}$, the division of the stream of carrier gas (helium) was 10:1, flow through the column at $1 \mathrm{~mL} / \mathrm{min}$. and a linear speed of $36 \mathrm{~cm} / \mathrm{sec}$. The programmed temperature was used: $60^{\circ} \mathrm{C}$ for $1 \mathrm{~min}$, then temperature was increasing in $10^{\circ} \mathrm{C} / \mathrm{min}$ steps until it reached its maximum value of $250^{\circ} \mathrm{C}$ (held for $1 \mathrm{~min}$ ). The analyses were performed using a capillary column HP-1 MS (Agilent Technologies) with a length of $30 \mathrm{~m}$, a diameter of $0.25 \mathrm{~mm}$, and a thickness of $1 \mu \mathrm{m}$ film. The transfer line was maintained at $250^{\circ} \mathrm{C}$, MS source temperature was $230^{\circ} \mathrm{C}$ and the quadrupole temperature $150^{\circ} \mathrm{C}$, dwell time - $100 \mathrm{~ms}$. The samples were analysed by the sum of four components: phenol $(\mathrm{m} / \mathrm{z}=94, \mathrm{RT}=$ about $7.78 \mathrm{~min})$, naphthalene $(\mathrm{m} / \mathrm{z}=128$, $\mathrm{RT}=10.04 \mathrm{~min})$, phenanthrene $(\mathrm{m} / \mathrm{z}=178, \mathrm{RT}=$ about 17.67$)$ and anthracene $(\mathrm{m} / \mathrm{z}=178, \mathrm{RT}=$ about $17.79 \mathrm{~min})$ in selected ion monitoring acquisition (SIM). Despite close relations and retention parameters $\mathrm{m} / \mathrm{z}$ ions for isomers: phenanthrene and anthracene achieved adequate separation of peaks.

\subsection{Statistical analysis}

The data were analyzed in STATISTICA12. Levene'a test of homogeneity of variances, ANOVA and HSD Tukey multiple comparisons of means were used to determine, which means are significantly different from each other.

\section{Results}

In presented experiments two methods of sterilization were tested. One of them was UV radiation and another one was sterilization in autoclave. We observe that in all solutions containing soot sterilized in autoclave no organisms were detected on Petri plates with agar LB MIX. However, UVradiation turned out to be useless for soot sterilization. All Petri plates shown bacteria colonies when medium with soot UV radiation treated were spread on agar plates (Tab. 3).

Average number of bacterial colonies was similar when soot produced during combustion without additive (UM) and with newly developed additive (Fe-additive) were used. It is also worth to notice that average number of the bacterial colonies is almost the same when cultures without soot were compared with samples treated with UM or Fe-additive soot. Additionally, the number of colonies grown in presence of $\mathrm{Cu}-$ additive soot was about $50 \%$ lower than in the samples without soot or in the samples treated by UM and Fe-additive soot.

When biodegradation of soot components were tested it was observed that the bacteria inoculated into soot suspensions were alive during whole 4-weeks period of experiments.

The HS-GC-MS analysis of the sum of the four selected aromatic components has shown the changes in the chemical composition of soot due to the two bacteria strains used for biodegradation (Fig. 1).
Table 3. Effect of different types of soot on growth of two strains of soil bacteria i.e. B. subtilis and P. aeruginosa.

\begin{tabular}{|c|c|c|c|}
\hline \multirow{2}{*}{ Type of soot } & $\begin{array}{c}\text { Soot } \\
\text { concentrat } \\
\text { ion }\end{array}$ & $\begin{array}{c}\text { No. of } \\
\text { B. subtilis } \\
\text { colonies }\end{array}$ & $\begin{array}{c}\text { No. of } \boldsymbol{P} . \\
\text { aeruginos } \boldsymbol{c} \\
\text { colonies }\end{array}$ \\
\hline \multirow{2}{*}{$\begin{array}{c}\text { Soot without } \\
\text { additives }\end{array}$} & $0.3 \%(\mathrm{w} / \mathrm{v})$ & $10.2^{\mathrm{a}} \pm 3.8$ & $11.1^{\mathrm{a}} \pm 3.0$ \\
\cline { 2 - 4 } & $0.6 \%(\mathrm{w} / \mathrm{v})$ & $9.4^{\mathrm{a}} \pm 2.5$ & $10.5^{\mathrm{a}} \pm 1.7$ \\
\hline \multirow{2}{*}{ Fe-additive soot } & $0.3 \%(\mathrm{w} / \mathrm{v})$ & $9.8^{\mathrm{a}} \pm 2.5$ & $10.9^{\mathrm{a}} \pm 3.5$ \\
\cline { 2 - 4 } & $0.6 \%(\mathrm{w} / \mathrm{v})$ & $9.6^{\mathrm{a}} \pm 1.7$ & $10.1^{\mathrm{a}} \pm 3.5$ \\
\hline \multirow{2}{*}{ Cu-additive soot } & $0.3 \%(\mathrm{w} / \mathrm{v})$ & $4.1^{\mathrm{b}} \pm 2.0$ & $3.8^{\mathrm{b}} \pm 2.5$ \\
\cline { 2 - 4 } & $0.6 \%(\mathrm{w} / \mathrm{v})$ & $4.2^{\mathrm{b}} \pm 1.5$ & $4.5^{\mathrm{b}} \pm 2.5$ \\
\hline $\begin{array}{c}\text { Control - bacteria } \\
\text { without soot }\end{array}$ & $0 \%$ & $10.6^{\mathrm{a}} \pm 3.5$ & $10.9^{\mathrm{a}} \pm 3.5$ \\
\hline
\end{tabular}

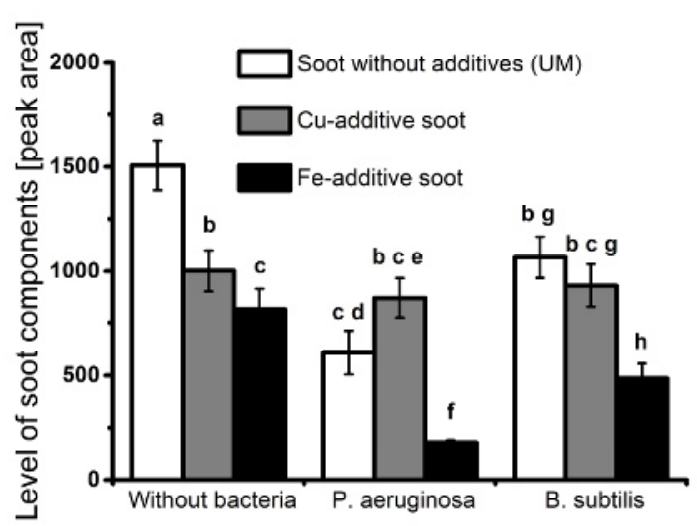

Figure 1. Comparison of the sum of: phenol, naphthalene, phenanthrene and anthracene analysed by (HS-GC-MS) in the biodegradation studies; in three soot types.

Table 4. The degree of biodegradation of aromatic compounds in soot samples.

\begin{tabular}{|c|c|c|}
\hline Type of soot & $\begin{array}{c}\text { Level of } \\
\text { biodegradation } \\
\text { with } \boldsymbol{P} \text {. aeruginos } \boldsymbol{\text { a }} \\
\text { [\%] }\end{array}$ & $\begin{array}{c}\text { Level of } \\
\text { biodegradation } \\
\text { with } \boldsymbol{B} \text {. subtilis } \\
\text { [\%] }\end{array}$ \\
\hline $\begin{array}{c}\text { Soot without } \\
\text { additives }\end{array}$ & 59.6 & 29.2 \\
\hline Fe-additive soot & 77.9 & 40.2 \\
\hline Cu-additive soot & 13.2 & 7.2 \\
\hline
\end{tabular}

After four weeks of biodegradation it could be observed that $P$. aeruginosa is more efficient in degradation of all soot types components than B. subtilis (Fig. 1, Tab. 4). Although tested components of all using types of soot could be degraded by bacteria, the best biodegradation was observed for soot formed during combustion with the new-developed additive, i.e. Fe-additive (Fig.1, Tab. 4). The lowest degree of biodegradation was detected for Cu-additive soot (Fig. 1, Tab. 4).

The degree of biodegradation (Tab. 4) was compared to the results obtained from soot without and with bacteria after 4-weeks incubation. The biggest declines in the value of biodegradation degree were recorded for Fe-additive soot (77.9\% for $P$. aeruginosa and $40.2 \%$ for $B$. subtilis cultures). 


\section{Discussion}

Soot as a pollutant is an important factor affecting biosphere. Because of its toxicity, reducing soot production is one of the primary tasks in modern energy production. One of the most efficient ways to reduce soot formation is the use of fuel additives [8]. On the market there are many additives to the coal as a solid fuel-reducing soot formation. However their influence on toxicity of soot formed during coal combustion with these additives has not been enough documented. Similarly, not enough attention has been also paid to the question what various additives to solid fuels modulate interaction soot - soil microbes including biodegradability of soot by these microbes. In our studies we compared effect of two solid fuel additives on soot toxicity on soil bacteria and how these additives result in soot biodegradability by these bacteria. The first was commercially available and commonly used additive containing significant quantities of $\mathrm{NaCl}$ and copper (Cu-additive). The second one was newly developed, $\mathrm{NaCl}$ free additive with $\mathrm{Fe}_{3} \mathrm{O}_{4}$ instead of based on copper compound items (Fe-additive).

To study the interaction soot - bacteria, soot sterilization method is required. Our results have shown that although dry sterilization by UV radiation was ineffective, moist heat sterilization in autoclave can be used successfully.

Effect of three different types of soot on growth of the two most common strains of soil bacteria i.e. P. aeruginosa and $B$. subtilis was tested. In the case of both tested bacterial strains, regardless of types and concentrations of soot bacteria growth was observed. Thanks to the applied dilutions, performing the quantitative tests was possible. Obtained results clearly confirm that using the additives increase efficiency of fuel combustion [9]. It is worth to notice that although sum of phenol and three selected polycyclic aromatic hydrocarbons (PAH) was lower in Cu-additive soot, the toxicity of this soot were the highest (Tab. 3).

The large number of primary components of fuels, complex combustion mechanisms and the heterogeneous interactions during soot formation made that soot is a mixture of various chemical components [10]. Our results shown that phenol, naphthalene, phenanthrene and anthracene were not responsible for soot toxicity on soil bacteria (Tab. 3). The highest toxicity of $\mathrm{Cu}$-additive soot arise probably from contents of $\mathrm{NaCl}$ and $\mathrm{Cu}$. Both $\mathrm{NaCl}$ and $\mathrm{Cu}$ are known as factors adversely affecting on the soil microflora $[11,12]$.

Using of fuel additives in coal combustion has positive influence on an industry, but also might have negative impact to the environment. The basic components of a majority of fuel additives are $\mathrm{NaCl}$ and $\mathrm{Cu}$ compounds. The use of $\mathrm{NaCl}$ has a positive effect on increasing the efficiency of the energy sources combustion, but also is responsible for releases of small quantities of nitrogen oxides $\left(\mathrm{NO}_{\mathrm{x}}\right)$ and carbon monoxide $(\mathrm{CO})$. On the other hand the compound during its combustion is a source of gaseous chlorine and hydrogen chloride and it is responsible for heating devices corrosion. Those gases contribute to the formation of particularly dangerous organochlorine compounds like dioxin. Copper salts not only efficiently catalyze oxidation of soot, but also may be responsible for a formation of other toxic xenobiotics [13].

It can be concluded that soot obtained from combustion with newly-developed additive with Fe-compound is not only less toxic but also will be more quickly removed from the environment.

Both Bacillus and Pseudomonas are typical soil bacteria [14]. The highest biodegradation rates were shown for P. aeruginosa (Tab. 3). This result can be attributed to a wide spectrum of hydrocarbon degradation, which is characteristic for bacteria of the genus Pseudomonas [15].

\section{References}

1. T.C. Bond, S.J. Doherty, D.W. Fahey, P.M. Forster, T. Berntsen, B.J. Deangelo, M.G. Flanner, S. Ghan, B. Kärcher, D. Koch, S. Kinne, Y. Kondo, P.K. Quinn, M.C. Sarofim, M.G. Schultz, M. Schulz, C. Venkataraman, H. Zhang, S. Zhang, N. Bellouin, S.K. Guttikunda, P.K. Hopke, M.Z. Jacobson, J.W. Kaiser, Z. Klimont, U. Lohmann, J.P. Schwarz, D. Shindell, T. Storelvmo, S.G. Warren, JGR: Atmospheres 118, 5380 - 5552 (2013)

2. J. Bachmann, Black Carbon: A Science/Policy Primer, Pew Center on Global Climate Change (2009)

3. R.F. Service, Science 319, 1745-1745 (2008)

4. W. Gehling, B. Dellinger, Environ. Sci. Technol. 47, 8172-8178 (2013)

5. P. Lu, C. Li, G. Zenga, X. Xiea, Z. Caia, Y. Zhoua, Y. Zhaoa, Q. Zhana, Z. Zenga, J. Hazard. Mater. 199, $272-281(2012)$

6. J. Lehmann, M. C. Rillig, J. Thies, C.A. Masiello, W.C. Hockaday, D. Crowley, Soil Biol. Biochem. 43, 1812-1836 (2011)

7. Ch. Anyika, Z.A. Majid, Z. Ibrahim, M.P. Zakaria, A. Yahya, Environ. Sci. Pollut. Res. 22, 3314-3341 (2015)

8. T. Farjon, O. Boinet, Soot disaggregating combustible agent, patent USA No. 5882365

9. E. Lipstein, Combustion catalyst, patent USA No. 8048234

10. H. Omidvarborna, A. Kumar, D-S. Kim, Recent studies on soot modeling for diesel combustion, RENEW SUST ENERG REV Renew. Sust. Energ. Rev. 48, 635-647 (2015)

11. Ch.L. Dupont, G. Grass, Ch. Rensing, Metallomics 3, 1109-1118 (2011)

12. M. Diaz-Raviňa, E. Bååth, Appl. Environ. Microbiol. 62, 2970-2977 (1996)

13. M. Chyc, Research Reports of Central Mining Institute, Mining Environment 1, 5-17 (2012)

14. D. Hank, N. Saidani, A. Namane, A. Hellal, J. Eng. Sci. Technol. Rev. 3, 123-127 (2010)

15. M. Kumar, M.P. Singh, D.K. Tuli, Adv. Microbiol. 2, 26-30 (2012) 